\title{
TRADITIONAL HOLIDAYS AS A METHOD AGAINST THE FORMATION OF “A POOR QUALITY PERSON”: WORLD EXPERIENCE
}

\section{Diachuk V. P.}

\section{INTRODUCTION}

Each objective phenomenon has its own determinant factors. They are reasons, conditions of its formation, roots. The knowledge about the causes and prerequisites of "low-quality" forms of the social and individual human being, the information, dealt with the determination of "low-quality" socio-cultural life of the society and people are highlighted in numerous socio-humanitarian studies as well as in natural sciences medicine, ecology, etc.

The basic concept of culture is analysed in J.-G. Herder's book, "Ideas for the Philosophy of the History of Humanity", written in 1784-1791. It was translated into many languages and gained great popularity. For example, there were many his followers in the Russian Empire. N. Karamzin, a historian, liked that book very much. M. Gogol, a Russian and Ukrainian writer and folklorist, said that J.-G. Herder was the greatest architect of the world history. J.-G. Herder believed that man was a higher creation whose main purpose was to develop the mind and the spirit of humanism. In his opinion, the education and upbringing lead people to the moral excellence. The humanity was destined to undergo several stages of culture in order to achieve harmony of feelings, reason, faith and justice. However, people are only at the beginning of their path, because there is still a lot of ignorance and crimes against humanism ${ }^{1}$ [1]. History shows that the development of culture is not a straight line. There are many turns, breaks and ledges. Human passions turn its calm stream into a waterfall that takes people's lives. Outrageous crimes, bloody wars, despotism, slavery and degrading human dignity constantly hurt the culture. However, it has an extraordinary margin of the strength and durability. So, one of the tasks of the study of cultural processes is to analyse the formation of a thinking individual. It is also the task such a new field of scientific research as "Management of Socio-cultural Activity". The whole system of knowledge in the management of socio-cultural activities is focused on ensuring the quality of life of the individual and social groups. The clarification of the

${ }^{1}$ Herder J. (1977). Ideas, Dealt with the Philosophy of Human History. [A. Mikhailov, trans.]. Moscow: Nauka. 
popular concept of "quality of life" is among the tasks of the theoretical and applied researches. It is used as a complex political-economic and interdisciplinary concept. However, its interpretations, by different authors, concern the specificity of the social and humanitarian problems, whereas there is a need to highlight its importance as a general socio-cultural concept. The unsatisfactory quality of social existence, "a poor individual" is the product of one's subjective ratings, impressions or opinions. These are the objective phenomena of social life and its general historical attributes. At the same time, there are significant political, economic and socio-cultural dimensions in the poor quality of social life.

Mastering the sociocultural aspects of the problem of "low quality" life of the society and people we should understand the fact that the formation of "a poor quality" person and "low quality" society is not the law of history or any society. People understand the phenomenon of "low quality", the increase of risks in the life of society and humanity because there are their opposite phenomena such as positive, healthy forms of social material and spiritual production, social relations, the rational ways of the organization of individual life, etc. Therefore, each individual manifestation of human and social existence can be good or bad, "low quality" or "high quality". The development of each individual depends on the determinants or destiny, which are some secret mechanisms of his or her happiness or unhappiness, satisfaction or dissatisfaction in their own lives. It is known that the category of fate was formed in the Ancient times as a reflection of the ignorance of these secret mechanisms and people's hopes to control them. According to the sociocultural vision of this problem, there is no condemnation for a "poor quality" life and poor development of his personality in the life of each individual. There is an increasing awareness of the general purpose of socio-cultural activity, which is to meet the needs of the individual's improvement, adaptation to the requirements of society and socio-ecological environment, in accordance with the impact on social and ethnic groups.

\section{The concept of "A poor quality person": the main factors of its formation}

The scientific research usually requires the assessment of a cultural phenomenon or a form of the cultural activity in terms of its typological identity. So, we can distinguish the following types: culture;

- In terms of complexity, handling, accessibility - elitist and mass

- In terms of aesthetic images, symbols, special communication means (artistic languages, which need special education, cultural education of the 
subject of cultural activity and consumption - classical and popular (pop) culture;

- In terms of official recognition, support by society, the state - official culture, subculture;

- In the context of the origin of culture's characteristic types in the historical era - the culture of primary society, the culture of the era of slavery, the culture of pre-industrial society, the culture of the era of industrial society, the culture of post-industrial society; pre-modern culture, modern culture, postmodern culture;

- In terms of the large socio-economic groups (class, social stratum or layer) - the culture of workers, the culture of the intelligentsia, the culture of peasants, etc.;

- In terms of the particular professional groups (the groups are formed or used by a professional group) - the students culture, the culture of education workers, the culture of health care workers, the culture of sportsmen.

In addition, there are many internal streams in every type of material and spiritual types of cultural activity. They use various means of communication (methods of formation of artistic images, symbolism, etc.). The artefacts, produced within a separate field of cultural activity, act. In many cases, experts use typological designations, which are formed because of the lack of the artistic values, its anti-communication (ignorance of cultural languages, means of formation of artistic and aesthetic image) kitsch, glamor, primitive, etc.

The sociality of transformation into a social individual or cultivation is belonged to the complex of factors, which influence people. Mass culture (from the Latin mass-com, piece and culture - user, creation) directs the failure of spiritual and life opportunities to the "average" level of the development of the consumer. However, the production of "mass culture" does not differ from any other mass production of the goods. So, the synthesis of higher art and mass culture is impossible. The mass culture is the result of "artistic activity" of the social life, which has been continuing since the ancient times. Mass media made it widespread and inclusive. The universal unit of the imagery in mass culture is a kitsch. The etymology of this word is difficult. Today we have the following versions of it: 1) in the German musical jargon of the early twentieth century "kitson" means "trash"; 2) in German the word "verkitsohen" means to be low quality; 3) in English the word "kitchen" means "for the kitchen", which is tasteless. This is the form, which has too many exterior useless and primitive details. The key attribute of the mass culture is a star cult, which means a hyperbolized cult of celebrities such as artists, actors, musicians and athletes. Nowadays, we can see such tendencies in political sphere, to make politicians be style icons, and the movie actors become politicians. So, the anchor people 
begin playing a great role in the society, whose personal popularity are based only on created images. This specific topic was relevant to the Ukrainian person and was developed in political processes.

Today, the public movements and civil organizations that use ecobroadcasting, environmental journalism, eco-culture are relevant. They try to clean the TV programs from the anti-humanism maintain the moral values of the society. For example, in the UK, such organisation is the "National Association of Viewers and Listeners" that analyses the informational situation in the domestic media. Comparing the Ukrainian media and British ones, we must say about the "oligarchic media gap" in our state. So, our media are oriented on the "quick rating" by the messy discussion, sex scandals, criminal and gossips. The viewer is offered a "marginal modern TV product". Besides, the marginalization as a process of removing the individuals or national groups from the social national framework leads to the transformations, which can be manifested in the following forms: the destabilization of social culture, the population of social activity, and the adaptation of social degradation.In sociological discourse, the concept of "marginal individual" was introduced by E. Park ${ }^{2}$ [10]. Defining the factors of the marginalisation, he focused on conflicts market economies, transformational processes and urbanization. In E. Park's opinion, the marginality as a source of the transformation, particularly in the cultural field. Describing marginalization in the context of globalization, E. Giddens and U. Beck emphasized that the creation of the new criteria and social identification and their combination with cultural and civic pluralism ${ }^{3}$ [7]. G. Simmel and E. Stonequist wrote that the marginal person is the source of the conflict confrontation in the society ${ }^{4}[11]$. Moreover, according to Z. Bauman in the modern world, the marginalization leads to the threat of the elimination of the social identification. Based on a number of sociologist researches, dealt with the interests of young people in the East of Ukraine (Donetsk region, Luhansk region), we can underline the following positive and negative tendencies: positive (stability, rationality, freedom of views) and negative (cynicism, nihilism, modern autism). We can overcome the negative effects of marginalization, in socio-economic and political spheres, by the establishment of civic activism and active civic culture. It is one of the basic structures of the modernization in accordance with present challenges. G. Almond,

${ }^{2}$ Park, E. (1997). Cultural Conflict and Marginal Person. Socialnye i humanitarnye nauki. Otechestvennay i zarubezchnay literatura. Series 11: Sociologia, № 2.

${ }^{3}$ Beck U. (2003). Cosmopolitan Society and its Enemies. Journal Sociologii i Socialnoi Anthropologii, Vol. VI, Issue 1.

${ }^{4}$ Stonequist, E. (2006). Marginal Man: the Study of Personality and Cultural Conflict. Lichnost'. Cultura. Obschestvo, 1. 
S. Verba, F. Hughes, F. Hickspurs include in the concept of civic culture "... a number of the contradictions in the desires, ideas, values, regarding the society, which form the basis of productive solution to the political problems and contradictions of different types, which stimulate the tension in society" 5 [13]. However, the civic culture as the key element of the political life plays the important role in the various spheres of the society. Moreover, the civil culture can be represented at the level of the whole country as the culture of consent. The civic culture is a part of the civic education, which is aimed at the socialization of the individual. The institutions of the civic socialization include both direct influence on the individuals (school, propaganda, etc.) as well as rapid process, which are out of any control (informal groups). The manipulation transform the young people into the aggressive or faceless indifferent mass. The media elite will not stop using such tools of the image for humanistic reasons. Therefore, the researches of the media strategy and tactics are actual. A wide- ranging program of educational programs and conscious projects on the correction of information culture and spiritual-moral institutions should be brought out. In our opinion, our society needs to build the system of the forming the informational immunity.

The manifestations of cultivation are adaptation of the individual to the material and spiritual culture, which is an attribute of the vital activity of the society; mastering of the verbal language and other forms of cultural communication; the development of cultural needs and interests. According to the data of physiology and psychology, only the potential opportunities for the development, the inclination for certain activity are innate.

So, the person can achieve many things in his development. So, in Thuringia during two centuries the six generations of the Bachs gift many flutists, organists and violinists. Therefore, every musician was called Bach and every Bach was called a musician. However, this example does not exclude the particular impact of social conditions and the need for some education. The issue of the inheritance of intellectual abilities is paid attention, which determine the development of mental and cognitive skills. Genetic scientists have proven that normal humans are capable of unlimited spiritual development because the possibilities of the human brain are endless. For example, Norbert Wiener (1907-1978), a founder of cybernetics, an American scientist, was awarded the title of professor at 14 years. We can say about the great influence of his family, which determine his development. Family communicative behaviour, family traditions have formed opportunities to generate interest in the scientific exploration. The moral and ethical culture, traditions of

${ }^{5}$ Heunkks, F. \& Hikspoors, F. (1993). Political Culture in 1960-1990. Paper prepared for the EVS-symposium on European Values. Leugen, September, pp. 16-19. 
communication and relationships within the family are important. In any sphere, the specific forms of moral relationships are the relationships of mutual concern, assistance, support, mutual respect, trust, sincerity, gratitude, generosity, complicity, empathy, love and loyalty. Each family develops a certain style and character of relationships. If they are stability, these or other relationships become habitual ones. We can call them traditional. The successes and failures of each family member (both adults and especially children) are shared in many families. If one becomes ill, they try to help and support in treatment as well as in the service and educational affairs. These small family traditions are an inseparable element of the moral and family nature, which is the key element of the high moral personality culture. The cultural leisure is important in various family traditions. The free time makes the problem of leisure become an increasingly important social problem. Psychologists and cultural scientists are writing about rationalization, leisure optimization. Teachers and parents point out the lack of leisure time and the increasing workload of schoolchildren. The lawyers consider a low leisure culture as a main cause of crime and illicit behaviour. Obviously, when we talk about a "sick society" we take into account all the factors that influence the formation of "poor quality individual". In this regard, it is necessary to have a clear position of leisure and its cultural organization both on a large social scale and on a family scale.

Leisure time is a free time from work or other mandatory activities. At this time, people freely (but within the rules and norms of the human coexistence) spend time in accordance with their interests and inclinations, their spiritual and physiological needs. Leisure can be classified as active and passive, cultural and non-cultural, individual and collective, family, school, public, etc. With the increase of the level of education, the development of sources of information, the modern family has the opportunities to vary its leisure. So, it is very important to take into account the child's psyche, which is not formed and is very exposed to television. The over-watching TV shows often leads to eye problems, TV addiction, dulling of the emotional perception. Therefore, the parents should reasonably direct the child's activities in the leisure time. The parents should do their best to make their family leisure be active, diverse, and contribute to the spiritual growth for both parents and children. Family leisure has occupies the special place in the development of moral and aesthetic culture. First of all, the family creates the most intimate living conditions of people, their communication and relationships. Secondly, many people spend much of their free time in the family environment. Thirdly, the family leisure is characterized by relative stability and related with family traditions and customs. 
In organisation of the family leisure time, the ability of adults to use their time and to teach their children use free time are very important. It depends on the ensuring, efficiency in everything and understanding. We can teach children by the proper mode of the day, demarcate their work responsibilities with their parents, and check out the simple rules of the family and people's coexistence. We should note that the main means of the formation of the spiritual riches of children are unformal methods: to tell a fairy tale (later - other books), to talk about the lives of the normal and outstanding people; toys and then engaging in creative amateur activities; walks to the woods, cinema, theatre, and museums. The rational time must be the family traditions. Reading is the key element of the leisure. However, the level of readership in the knowledge of children and adults is far from desirable. Parents very rarely help children with their choice of literature. It is necessary to distinguish such a family tradition when they trust in communication with children, discovering the diversity of the world around them. It is important in moral and aesthetic aspects because it develops the children rationalism, their thinking. In order to form the emotional world of the children it is necessary to develop and refine such a tradition as joint games (concerning mindful games, intellectual, which enrich the spiritual world of a person). They are home geographical trips, historical quizzes, various linguistic competitions. The perfect way to do it is to transform fun, exciting games into family traditions.

The collective family walks are of great importance in the cultural organization of family leisure, especially in urban space. It is important that they become a habit. So, they become a small family tradition, and that is walking in common. Parents and children often walk alone not to interfere with each other. This is quite natural: the interests of adults and children are different because of age psychology, whereas the common interests should be. It depends on the ideological and moral atmosphere of the family, which should be managed.

It is very important in the organization of cultural leisure in the family to develop amateur activities (collecting, technical design, knitting, photography, mushroom gathering, flower growing, fishing, etc.), tourism, and intellectual family parties. The main tasks are to cultivate good habits of cultural rest and keep in mind that they are lost more easily than acquired. Positive leisure habits remain a long-standing tradition. The creation and support of the family traditions and organisation of the cultural leisure in the family are the basic condition of personality formation. 


\section{Traditional holidays as instruments of the formation of socio-cultural identity: world experience}

In ancient times, philosophers and historians tried to determine the phenomenon of human leisure activities, the need and purpose of the holiday and to find out their role in the society. This problem remains the subject of research by the scientists today. The multi-functionality of leisure activities: the restoration of life, emotional and psychological orientation, ideological, moral and educational and other functions prove the great significance of the holidays, especially, calendar ones, which are closely connected with the cultural tradition of peoples. The holiday is the main link in the person's leisure. The familiarity with this phenomenon will allow us to consider the features of leisure activities of different peoples of the world in everyday life and to get acquainted with the culture of the countries.

Leisure in Bulgaria. The Bulgarians respect the ancient rites and rituals. The longest vacation they have during national and religious holidays. Every year in Bulgaria January 21 celebrates "Grandma's Day". This is a holiday of the grandmother-wives. The grandparents were given presents and bouquets of flowers tied with red ribbon. In many places, people celebrate the merry feast of sons-in-law who live in the home of the wife's parents. It is not easy a son-inlaw to live and follow the rules: to be tolerant, to love your father-in-law and mother-in-law as your parents, to thank them for what it is he was chosen in a son-in-law, not to deny them even mentally, to name the children in honor of his mother-in-law and father-in-law, and to tell everyone that they are like relatives of his wife and have all their positive features. This holiday is an educational moment for both young people who married, come into another's family and for those who accept them. There is also a "moustache union". In Bulgaria, moustaches have always been a sign of masculine nobility. Therefore, all men, who were admitted to this union, were obliged to help in ordering the city and to help the sick on the farm. The money they make is used to organize the moustache festival, during which those who have moustaches, different in length, shape and colour, parade down the street, entertain people with songs and dances.

Leisure in Finland. Finns like to go for a walk in the evenings and weekends, often giving this time to sports. One in four people in the country is a member of one of the sports organizations. The most popular sports are skiing, rowing, jogging and wrestling. The Finns, like other peoples of Europe, celebrate the 1st of April as the Day of Laughter. According to some scholars, the "Day of Deception" came from the East. Similar customs have existed in India, China, and Japan since ancient times. However, this day the European peoples gained local colours. It manifests a sense of humour, optimism, cheerfulness and people's belief in everything. 
In Finland, the first championship for the production of birdhouses was held in 1994. The reason for this unusual competition is the traditional love of the Finns for the birds, and the production of birdhouses is one way of detecting it. The country's nature protection union organized the championship. There are many different unions in the country. One of them is Skepsis. At the end of each year, its members announce their decision to award the most ridiculous book with a certificate of honour. For example, the "Nonsense -99" diploma marked the "Werner Sederstrom" edition house, which published "Astrologer's Handbook". Its authors advise readers to tell their superiors about their zodiac to avoid any conflicts.

Leisure in Japan. The Japanese are calm and do not express their feelings. However, once a year, on the eve of the New Year holidays, they can relieve tension. This period is called the short cry period. The Japanese can knock their feet on the street lights, throw the garbage, scream all over their throats, giving out emotions. In the cities, there are many competitions of the screamers, which depend on their content. You can shout at any topic, but there are also competitive tasks. For example: "What was the most unpleasant for me this year?".

The Japanese New Year's holidays include the diversity of customs and rituals, associated with the expectations of people for a safe, happy and successful year. There is a special name for the first day of the New Year - "Ganjutsu" "Starting Day", which means "revival” or "embarking on a new journey". It can also be expressed by the words: "if you have lost the road, it is better to start from the beginning". On the eve of the holiday, the special attention is paid to cleaning the house. It is called "cleaning from soot". A pine tree is one of the necessary components of the decoration of the house. It symbolizes strength, firmness, longevity, health, a joyful and happy life. Another indispensable part of the decoration is bamboo, which is a symbol of resilience, resistance to the hardships of life, and the rapid prosperity. The Pine and bamboo are connected by a straw harness, which is entitled a sienava. According to popular beliefs, these plants protect against evil spirits and misery. A special dish on the New Year's table is the adzuki that is a porridge with vitamin $\mathrm{B}$. The porridge is made from small red beans and rice, which are long soaked in plenty of water until the mass thickens. According to the old tradition, only men can prepare this dish.

The girls' holiday (Hinamatsuri) is one of the significant March holidays. The holiday marks the arrival of spring, which is an important event in the life of the peasants. If family has a daughter, the parents have to exhibit many dressed dolls in the house that reflect the customs of the imperial court. People also exhibit all kinds of colourful toys. In the Japanese's understanding, the dolls are the symbolic representations of gods. They have long served as the protection against disease, natural disasters and other misfortunes. 
Tau-saei is a holiday of planting rice, which is celebrated in all villages. Rice is considered a living creature with its consciousness and will. It is very offensive, does not tolerate the slightest inattention and needs to be well pleased and entertained. Autumn in Japan is rich in holidays, associated with the cult of nature. The holiday of the Moon is one of the most important among the Japanese autumn holidays. It is believed that it gives people health, adds age, and brings happiness, luck, prosperity.

The Japanese celebrate the holiday of children, which can be translated as "seven", "five", and "three". Therefore, they celebrate the birthday of the children at the age of three, five and seven years. The parents arrange fun nights for them with songs, dances, treats. The children receive inexpensive but memorable gifts. Balloons, souvenirs and sweets are sold on the streets especially for children.

Leisure in Britain. The special historical development of the UK influenced many aspects of its social life and its content and nature of leisure. Britain is a well known by its sports game. Cricket, skittles, racquets and the others are its national games. There are many different unusual clubs in the state. The dangerous sports club is one of them. The dinner on the volcano is one of the eccentric pastimes of this club. They accept their members at the highest cliffs in Scotland. After it, the newcomers have to dive in the cold ocean water. However, the jumps from bridges and skyscrapers are the popular kinds of the entertainment.

Another event has been holding for 700 years. The apple market was opened in 1267, in the English city of Egremont. The competitions are rather exotic, though traditional for this holiday. They are the crawling on a pillar, smeared with fat, the competitions of the bards that sing sentimental, humorous and hunters' songs. The key event of the holiday is the championship of the funny faces. Many people try to show the funniest face.

The pancake race is one of the English traditional holiday. The competition means that the youth women have to run to the finish, bringing a hot pan with a pancake in their hand. The winner is the woman who quickly finish the distance, turning her pancake without letting it drop. The taste of the pancakes are not taken into account.

Leisure in Brazil. The Brazilian national culture is the combination of Portuguese, Amazonian and African traditions. Carnivals are the favourite leisure of the Brazilians, who perform complex, exotic dances, such as Samboba-Tata. This dance, performed in a circle and accompanied by choral singing, reflects the process of collecting sugar cane. The special groups are the ritual and magic dances. The latter are popular in medicine, treatment from the "bad eye”, in case of financial complications and love failures. Every year the Brazilians celebrate the Mother of Water holiday. People prepare the special 
gifts for the goddess. People put them in the decorated boats and lower to the deepest places of the sea or lake, accompanied by ritual singing. In the evening. They arrange dances in African costumes in honour of the Mother of Water.

The Brazilian children and adults like to play the game "cat in a bag". The players throw a half-meter bamboo stick into the ground. A coin is placed on top of the bamboo stick, and drew a circle around it. The players try to knock the coin by another. However, the coin should fall to the ground outside the circle. Who does it, gets a point. The points are scored after the tenth round. The one who got the most part of the points wins. "Cat in the Bag" is a game, which is well known in all Latin American countries. It requires a wide bag with "gifts" for players. They can be rags, coloured pebbles, old ropes, torn boots and more. The gifts are as many as players are. They take the gifts from the bag. After it, they have to thank it and tell how to use the unusual gift. The most successful and fun answer is awarded with a prize.

Leisure in China. The Chinese believe that the rest is an assistant of work. On the first day of winter, the Chinese celebrate the Day of their Ancestors, which is entitled preparing the winter clothes to the souls of the dead. The handmade paper clothes are burned according to a certain ritual. The Chinese celebrate the winter solstice, which is considered a bad sign to quarrel, laugh and talk about unpleasant things. The New Year's meeting plays the special role in the ceremonial holidays. The rites of the New Year's Eve reveal the unity of the Chinese family, including its dead relatives. The souls of the dead who returned to their home were offered to taste the ceremonial dishes. According to the Chinese ancient customs, before the New Year, everything must be clean: our hearts, our relationships with others. The Chinese are giving extraordinary importance to the financial commitment of the coming year. There should not be any debts in the New Year. The Chinese proverb says, "The old dust in the rooms should not remain for the New Year".

Autumn is marked by the holiday of the Double Nine, which is followed by climbing hills and launching kites. The kites usually are made in the form of birds, butterflies, dragons, bats and other real and fantastic animals. The participants seek to ram an opponent's kite or cut its rope. A popular Chinese proverb says, "If a rope of a kite breaks, half the wealth will leave the house". Traditionally, Chinese people are fond of stone carvings, metal art, porcelain and ceramic products, weaving baskets and the creating of the artistic compositions. Recently, such areas of these arts as the production of paintings of seashells, chips, cotton threads, wool, and flowers of synthetic materials have been developing.

Leisure in Iceland. The country has little material historical monuments, whereas there are many literary and folklore memories. In times of joy, sadness, or solemn occasions, the Icelandic invariably likes poetry very much and 
composes poems himself. In addition, the schools have competitions of the verses. The teams must compose the answers to the opponent's poems that should begin with its last letter. They continue the competition until one of the teams runs out of poetic inspiration. According to the statistics, the Icelanders read a lot. Every Icelander tries to have a personal library. They also are go in for sports and various competitions. There are many fans of the traditional competitions in the country. They are carrying large stones, pushing boulders and pushing wooden poles. Fighting on sticks is another long-standing favourite game of the Icelanders. The game uses sticks about two meters long and three to four centimetres thick. The fighters split into pairs and the fight begins.

Leisure in Australia. Leisure activities in the family of an Australian entrepreneur, worker or farmer are indicated by relationships among members of the family. In Australian families, the custom of avoidance is common. It means the highest courtesy. The greatest attention is paid to the mother-inlaw, we should turn away, not look at her - to avoid them in every possible way. It is very widespread among indigenous people of Australia. The son-inlaw, seeing his mother-in-law is approaching, has to hide somewhere. He leaves the hiding place only when he is told that his mother-in-law went away. The only way to communicate is to turn their backs on each other and shout loudly, as if standing not near, but separated by a great distance. Many Australians spend their leisure time the same as the UK residents: they visit clubs, go in for sports, especially surfing the waves.

Leisure in the USA. In the United States of America, some small towns have introduced a "Quiet Day" rules. For example, in New Jersey, the small town of Osh-Grave passed the law that declared the last day of the week was the "Quiet Day". On Sunday, traffic is forbidden, streets are blocked by heavy chains and locked. In some areas, the cockroach competitions are held. The cockroaches are up to five centimetres in length. The people gather for the "World Cup of the Frogs' high jumps" and "Tarantula Racing”.

There is the tradition of sand sculpture championship on the coast of southern California. It is enjoyable for children as well as for adults. In the winter, the Americans participate in winter carnivals. For example, at the carnival in the town of Steamboat, Colorado, you can try your hand at traditional winter sports and see ski aerobics competitions. The Earth ball is the new mass sport game, which was invented by American Stuart Freud. The ball is so big that the players jokingly compare it to the globe.

Carson City celebrates the traditional festival of whistles, which brings together masters of artistic whistle from all over the country. Whistling in many countries was a means of communication. Until now, one of the Canary Islands has remained the language of whistling, invented by the locals in ancient times. Traditional inter-whistling can be heard everywhere in Guatemala and Mexico, 
Turkey and countries in Africa. Shepherds and peasants in Spain spoke a similar language.

Leisure in Austria. The most popular kinds of leisure are a variety of home handicrafts and photography. The Austrians go in for sports, particularly swimming and skiing. In Austria, at the end of the agricultural year, people celebrate St. Martin's Day. All the field works are completed. "Martin came, the work went". In November, the shepherds walk in the yards and beat their animals with birch, linden or juniper branches. They believe in magical power the branches to protect the animals.

Christmas in Austria is a family holiday when the family has a common supper. Earlier, they considered the strangers' visits at this time led to the bad news. However, the poor people are invited to the holiday table. In December, a special dressed people wish happiness and prosperity to the people, they are given money. The night of the old year has many different signs and prohibitions. For example, you do not have to lie in bed, even if you are sick. The dishes of December 31 is very fat. It is believed that in order to be happy, one has to remove a piece of head or pig's snout, which is called "participating in pigs' happiness".

Leisure in Sweden. There are many football stadiums, indoor and outdoor swimming pools, skating rinks, gymnasiums, cycle tracks and ski runs. In cross-country skiing, everyone from small to old is involved. Football and hockey are popular among men and women. A popular sport is cross running with maps and compass. There are many active unions in the city, which unite people, who are interested in painting, refinement, decorative art, photography, and movie art.

Christmas is the most popular holiday among the Swedes. The relatives visit each other. In the spring days of Easter, the families go out to the city. Young people traditionally move to the northern country for skiing where the snow still lies. On the Holy Trinity, the Swedes have a walk to the woods or to the lake for sail boating to the small rocky islands, which are not far from the continent. In summer, at the period of the white nights, all Scandinavians celebrate Ivan's day, the day of the summer solstice. It is celebrated on Saturday between June 20 and June 26. The holiday begins from Friday evening and lasts for three days. People light big fires and create the high e pole, decorated with garlands, green and yellow-blue ribbons. This pole is called the May tree. Around the fire and the May tree, in the morning, the old and small people, dressed in national costumes, dance and sing the folk songs, accompanied by violins and accordions around the fire. Young competes in jumping over a fire, bathes in lakes.

Leisure in Germany. The special features of the German character is orderliness, accuracy, cleanliness and economy. The German character actually 
influences the behaviour in leisure as well as the choice of its kinds. Every year, in the winter period, the Munich farmers organise the competition of riding on a sleigh from the mountain. The race is difficult, so sometimes the participants bring harsh jumps up to 20 meters long. It is both a joyful sport and a health. The falcon hunting is popular in Germany. Today, there are 40 clubs of this kind of leisure in Europe. In the northern region of Bremen, we can find even two special "falcon stadium", where people can watch the pirouettes of falcons hunting the doves and quails. Certainly, the falcons are well trained. The pig competitions are held in Lüneburg in the north of the country. Pigs run back and forth on a specially fenced highway 50 meters long. ${ }^{6}[14]$ Many people take part in the competitions of their professions, which popularize the professions in the society. For example, in Zurich, the restaurant owners annually create the barrier runs for waiters. The distance is one and a half kilometres. The waiters should bring to the finish a tray with a bottle of liqueur, a bottle of wine, a bottle of mineral water and a glass of the cocktail. So, they have to overcome all the barriers without breaking a any bottle and glass. The last winner won with the time 9 minutes 19 seconds.

All examples show that the peoples of the world spend their leisure time qualitatively and cheerfully. The main task of the society is not to give the electronic mass-product opportunity and the gadgets to repel the empathy to the society by the zombie influence. The typologisation of cultural systems is the basis for the deepening of the practical orientation of philosophical and cultural theories as well as for the elaboration of applied concepts and technologies.

\section{CONCLUSIONS}

The phenomenon of the poor quality person is the form of the manifestations of the negative effects of the marginalization of the modern society, which concerns the socio-economic, cultural, artistic, and political spheres of human being. The key ways to overcome this problem are to form the civic activity among youth and to show them the examples of the values of the civic culture, which are the basic constructs of the modernisation that determine the development of the individual, society, and state. The Spiritual and moral state of the individual will influence the economic culture, the development of new socio-economic relations and the socio-cultural priorities, such as understanding of life goals and tasks in the context of modern social reality. The traditional holidays are one of the best examples of the combination global and local moral values in the leisure industry.

\footnotetext{
${ }^{6}$ Leisuare culture / (Magazine news collection) / Завуч. 2007 august, pp. 38-47.
} 


\section{SUMMARY}

It is analysed the concept of the poor quality person, to highlight it as the objective phenomenon of the sociocultural being and distinguish the main factors, which determine its functioning in the society. In addition, the author evaluate and conduct the analytical observations of the knowledge system in the management of socio-cultural activities, aimed at ensuring the quality of life of the individual and social groups. The tasks of industry theoretical and applied research include the clarification of the well-known concept of "poor quality person" and its applying in the socio-cultural space of the modern society.

The author pays attention to the role of the traditional holidays and kinds of the leisure in the formation of the social and cultural identity in the various countries of the word: Bulgaria, Germany, the United States of America, Iceland, Japan, China, etc.

\section{REFERENCES}

1. Herder, J. (1977). Ideas, Dealt with the Philosophy of Human History. [ A. Mikhailov, trans.]. Moscow: Nauka (in Russian). (in Russian).

2. Tarde, G. (1999). Public Opinion and Crowd. Moscow: PCB

3. McQuail, D. (2011). Theory of Mass Communication: a handbook. Lviv: Chroniky(in Ukrainian).

4. Proleev, S.V. (1996). Encyclopedia of Vices: Justification of the Flaws and Weaknesses of Human Nature. Kyiv: Naukova Dumka (in Russian).

5. Sohan', L. \& Tykhonovych, V. (eds.). (1982). Personal Life Style. Theoretical and Methodological Problems. Kyiv: Naukova Dumka (in Russian).

6. Philosophical Dictionary. (1980). Moscow: Znanniya (in Russian).

7. Beck U. (2003). Cosmopolitan Society and its Enemies. Journal Sociologii i Socialnoi Anthropologii, Vol. VI, Issue 1 (in Russian).

8. Giddens, E. (2002). Towards a Global Age. Otechestvennye zapiski, №6 (in Russian).

9. Simmel, G. (2008). Excursion about a Stranger. Sociologicheskay theoriya: istoria, sovremennost, perspectivy. Almanac Sociologicheskogo Obozrenia. St. Petersburg: Vladimir Dahl (in Russian).

10. Park, E. (1997). Cultural Conflict and Marginal Person. Socialnye i humanitarnye nauki. Otechestvennay i zarubezchnay literatura. Series 11: Sociologia, №2 (in Russian).

11. Stonequist, E. (2006). Marginal Man: the Study of Personality and Cultural Conflict. Lichnost'. Cultura. Obschestvo, 1 (in Russian).

12. North, D. (2010). Understanding of the Process of Economic Change. Moscow (in Russian). 
13. Heunkks, F. \& Hikspoors, F. (1993). Political Culture in 1960-1990. Paper prepared for the EVS-symposium on European Values. Leugen, September 16-19 (in English).

14. Leisuare culture (2007).(Magazine news collection). Zavuč. august, pp. $38-47$

\section{Information about the author:}

Diachuk V. P., orcid.org/0000-0003-1638-3192

Candidate of Culturology, Associate professor, Associate Professor of the Department of Art Management and Event Technologies National Academy of Culture and Arts Management

9, Lavrska Str., 01015, Kyiv, Ukraine 